\title{
Plant Growth-Promoting Bacteria as Bioinoculants: Attributes and Challenges for Sustainable Crop Improvement
}

\author{
Ma. del Carmen Orozco-Mosqueda ${ }^{1, *}$, Aurora Flores ${ }^{2}$, Blanca Rojas-Sánchez ${ }^{2}$, Carlos A. Urtis-Flores ${ }^{2}$, \\ Luzmaria R. Morales-Cedeño ${ }^{2}$, María F. Valencia-Marin ${ }^{2}$, Salvador Chávez-Avila ${ }^{2}$, Daniel Rojas-Solis ${ }^{3}$ \\ and Gustavo Santoyo $2, *(\mathbb{D})$ \\ 1 Facultad de Agrobiología "Presidente Juárez", Universidad Michoacana de San Nicolás de Hidalgo, \\ Uruapan 60170, Mexico \\ 2 Laboratorio de Diversidad Genómica, Instituto de Investigaciones Químico Biológicas, \\ Universidad Michoacana de San Nicolás de Hidalgo, Morelia 58030, Mexico; aurora.flores@umich.mx (A.F.); \\ rojassancblanca@gmail.com (B.R.-S.); 1316102a@umich.mx (C.A.U.-F.); \\ luzmaria.morales@umich.mx (L.R.M.-C.); 1237718c@umich.mx (M.F.V.-M.); 1230673a@umich.mx (S.C.-A.) \\ 3 Laboratorio de Restauración Ambiental, Instituto de Investigaciones en Ecosistemas y Sustentabilidad, \\ UNAM, Morelia 58190, Mexico; daniel_rojas21@hotmail.com \\ * Correspondence: carmen.orozco@umich.mx (M.d.C.O.-M.); gustavo.santoyo@umich.mx (G.S.)
}

check for updates

Citation: Orozco-Mosqueda, M..d.C.; Flores, A.; Rojas-Sánchez, B.; Urtis-Flores, C.A.; Morales-Cedeño, L.R.; Valencia-Marin, M.F.; Chávez-Avila, S.; Rojas-Solis, D.; Santoyo, G. Plant Growth-Promoting Bacteria as Bioinoculants: Attributes and Challenges for Sustainable Crop Improvement. Agronomy 2021, 11, 1167. https://doi.org/10.3390/ agronomy 11061167

Academic Editor: Małgorzata Szczepanek

Received: 28 April 2021

Accepted: 5 June 2021

Published: 8 June 2021

Publisher's Note: MDPI stays neutral with regard to jurisdictional claims in published maps and institutional affiliations.

Copyright: (c) 2021 by the authors. Licensee MDPI, Basel, Switzerland. This article is an open access article distributed under the terms and conditions of the Creative Commons Attribution (CC BY) license (https:// creativecommons.org/licenses/by/ $4.0 /)$.
Abstract: Plant growth-promoting bacteria (PGPB) are excellent biocontrol agents and stimulators of plant growth, nutrition, and production. Therefore, these plant-associated bacteria are considered an excellent alternative to reduce or eliminate the use of toxic agrochemicals. In this work, we review the current state of the beneficial mechanisms (direct and indirect), including the production of antibiotic compounds and enzymes, facilitation of resource acquisition, or production of stimulating phytohormones/metabolites. Some aspects of the formulation technology and bioinoculant efficiency of diverse PGPBs (e.g., rhizobacteria, phyllobacteria and endophytic bacteria) in the field are also discussed. However, the commercialization and application of these biological agents in agriculture occur mainly in developed countries, limiting their success in developing regions. The possible causes of the delay in the application of bioinoculants for sustainable agriculture and the plausible solutions are also discussed in this study. Finally, the use of PGPBs is currently a priority for sustainable production in agriculture.

Keywords: plant growth-promoting endophytes; rhizobacteria; phyllosphere; agrochemicals; sustainable agriculture; biostimulants

\section{Introduction}

In the mid-20th century, an almost exponential growth in human population occurred in various countries worldwide. This increasing number of individuals caused an unprecedented demand for food and required an agricultural production that had not been seen before. In this regard, the "green revolution" helped meet this demand for food and products through the use of chemical fertilizers and pesticides, which led to a decrease in infections of plant crops caused by pathogens [1]. However, the excessive use of agrochemicals, which was more evident in some underdeveloped regions, has wreaked havoc on the environment and on human and animal health [2]. Even with the excessive use of agrochemicals, agricultural losses due to pathogens have not ceased, with up to $25 \%$ of the total world production being lost annually [3]. It has been proposed that food production by 2050 will need to double the present production. To achieve this goal, new alternatives that would result in an increase in agricultural production via eco-friendly, sustainable, and nontoxic strategies have been sought $[4,5]$. Thus, various strategies, such as the production of genetically modified organisms (mainly plants), the generation of crosses that are naturally resistant to pests, and the use of natural compounds and 
plant-beneficial microorganisms have been proposed [6]. The beneficial microorganisms that may be part of bioinoculants, whether these are biofertilizers, biocides, or biostimulants, may be beneficial fungi such as Trichoderma spp., arbuscular mycorrhizal fungi, and rhizospheric or endophytic bacteria [7-9]. A long list of commercialized bacterial inoculants, based mainly in plant growth-promoting bacteria (PGPB), has been reviewed by Glick [10]., and includes Agrobacterium radiobacter, Azospirillum brasilense, Azospirillum lipoferum, Azotobacter chroococcum, Bacillus firmus, Bacillus licheniformis, Bacillus megaterium, Bacillus mucilaginous, Bacillus pumilus, Bacillus spp., Bacillus subtilis, Bacillus subtilis var. amyloliquefaciens, Burkholderia cepacia, Delftia acidovorans, Paenibacillus macerans, Pantoea agglomerans, Pseudomonas aureofaciens, Pseudomonas chlororaphis, Pseudomonas fluorescens, Pseudomonas solanacearum, Pseudomonas spp., Pseudomonas syringae, Serratia entomophila, Streptomyces griseoviridis, Streptomyces spp., Streptomyces lydicus, and Rhizobium spp. However, the list is still growing, and new bacterial species with beneficial properties for sustainable agriculture are being described [11]. This work tries to explain the different mechanisms used by plant-associated bacteria, with special emphasis on bacteria inhabiting the rhizosphere (rhizobacteria), phyllosphere (phyllobacteria) and the plant endosphere (endophytic bacteria), as well as the different challenges to be applied in the field through efficient formulation that ensure the survival and action of their bacterial agents.

\section{An Overview of Plant-Associated Bacteria}

Bacteria can be associated and interact from below- or above-ground areas of the plant. Likewise, bacteria can penetrate the internal compartments of the plant and live inside. All these plant-associated bacteria might be able to exert beneficial mechanisms, such as direct and indirect (biocontrol) plant growth promotion (PGPBs).

\subsection{The Rhizobacteria}

The rhizosphere is the area of the soil that surrounds the root and is influenced by the excretion of root compounds. Root exudates contain vitamins and, amino acids, among other nutrients that can be acquired by rhizospheric bacteria, increasing their populations of those that have the greatest advantage to take them [12]. The term "rhizosphere" was coined by Lorenz Hiltner, and since its description, he had described it as a microenvironment where the bacteria that inhabit it ("bacteriorhiza") could interact and significantly influence plant nutrition [13]. Additionally, Hiltner had also suggested the visit of "uninvited guests," that adjust to the specific root exudates. According to Hartmann and colleagues [13], Hiltner also hypothesized that "the resistance of plants towards pathogenesis is dependent on the composition of the rhizosphere microflora". This idea has been confirmed by multiple studies, as the rhizosphere microbiome has a preponderant role in plant protection through the stimulation of the plant's immune system and the direct control of potential phytopathogens [14].

\subsection{The Phyllobacteria}

Plants can be colonized below-ground by rhizobacteria and above-ground by a variety of microorganisms, including bacteria. This aerial habitat, which includes leaves, stems, flowers or fruits surfaces that can be colonized by microbes is termed the phyllosphere, and the inhabitants are called epiphytes. One of the most common inhabitants of phyllosphere are bacteria, which are known as phyllobacteria (or phyllosphere bacteria). Usually, phyllobacterial species may face a lot of environmental changes (even during the same day) compared to rhizosphere or endophytic bacteria (see below), including wet or dry conditions, as well as tolerating UV radiation [15]. However, some specific points of colonization in the leaves are particularly protecting sites for phyllobacteria from these harsh abiotic factors, such as trichomes, veins, cell wall junction of epidermis and stomata. In addition, phyllobacteria can uptake nutrients for survival from phyllosphere and exert protection to the plant from the pathogens attack. For example, Pseudomonas species are able to 
avoid the Botrytis conidia attachment by changing the surface wettability [16]. Besides, phyllobacteria can stimulate the ISR plant system and stimulate plant growth [17].

\subsection{The Bacterial Endophytes}

Plants form associations with microorganisms in each and every corner of our planet. The microorganisms that interact with a plant are collectively known as the plant microbiome. The group of microorganisms that interact "more" closely with plants and live within their tissues are known as endophytes. Endophytes, or the plant endobiome if we refer to endophytic communities, have been proposed to have a long-lasting relationship as old as 400 million years $[18,19]$. Therefore, these microorganisms have evolved different types of plant-endophyte interactions, such as neutralism or commensalism, mutualism, and symbiosis. Of course, there are also harmful interactions with pathogenic endophytes, such as parasitism [20]. However, endophytes must have a non-pathogenic relationship with the plant. In other words, endophytes must be isolated from the surface of sterilized tissues and not produce any apparent damage to the host plant [6]. Thus, it is important to differentiate between pathogenic and non-pathogenic endophytes, since those that have beneficial interactions with the plant are the ones to be used in sustainable agriculture.

In general, two types of endophytes have been proposed. First, the long-term relationship endophytes, which are part of the core of endophytes "selected" by the plant. Long-term associations can be inherited vertically through seeds. Second, the short-term association endophytes, which are represented by those endophytes that tend to colonize the host through random mechanisms, such as colonization of cracks or damaged areas in the plant, mainly roots. This may be a way to facilitate their penetration of the plant internal tissues. To learn more about these colonization mechanisms and the types of interactions, several recent contributions are recommended [7]. Some authors refer to these short- and long-term associations as nonsystemic or systemic, respectively [21]. It is noteworthy to mention that these classifications are based on taxonomic characteristics, mode of transmission, lifestyle, host defense response, ecological functions, evolutionary pattern, and diversity.

\section{Beneficial Activities of PGPB}

The beneficial and promoting mechanisms of plant growth have been widely reported and reviewed in previous studies [7,10,22]. However, for the purpose of this work, it is relevant to review them to mention their importance in the application of PGPBs as bioinoculants in various agricultural systems. Rhizobacteria and bacterial endophytes, among other beneficial microorganisms, can stimulate the growth and health of plants through direct and indirect mechanisms that are described below (Figure 1).

\subsection{Direct Mechanisms}

The direct mechanisms of plant growth promotion include the facilitation of nutrient acquisition and the synthesis of hormones [10]. One of the main problems that plants face in acquiring nutrients is the poor solubility of the elements in the soil. For example, phosphorus is scarce in many soils worldwide, besides being in insoluble forms, limiting its use by plants. Plants generally obtain soluble phosphorus in two forms, monobasic and dibasic. Phosphorus is present in the soil as inorganic minerals, such as apatite, or as one of the several organic forms, including inositol phosphate, phosphomonoesters, and phosphotriesters [23]. Inorganic phosphorus is applied in the field as a chemical fertilizer, along with other elements such as nitrogen. However, as phosphorus is mostly insoluble, the plant does not use it and it leaches, contaminating the ground water reserves [24]. Therefore, the use of phosphate solubilizing PGPB, including genera such as Achromobacter, Agrobacterium, Bacillus, Enterobacter, Erwinia, Flavobacterium, Gluconacetobacter, Mycobacterium, Pseudomonas and Serratia, play a fundamental role in solubilizing insoluble forms of phosphorus, mainly through mechanisms such as the production of acid phosphatases, which help to mineralize organic phosphorus in the soil [22,23]. Likewise, the production 
of organic acids such as gluconic acid and citric acid by PGPB help in the solubilization of phosphorus, in such a way that, when plants acquire these solubilized or mineralized molecules, their growth and production can be stimulated [24]. Moreover, production of organic and inorganic acids such as citrate, oxalate, acetate, sulfuric acid, carbonic acid and nitric acids by PGPB, also stimulates the solubilization of other elements, such as zinc and potassium, which are essential for soil fertility and crop improvement [22].

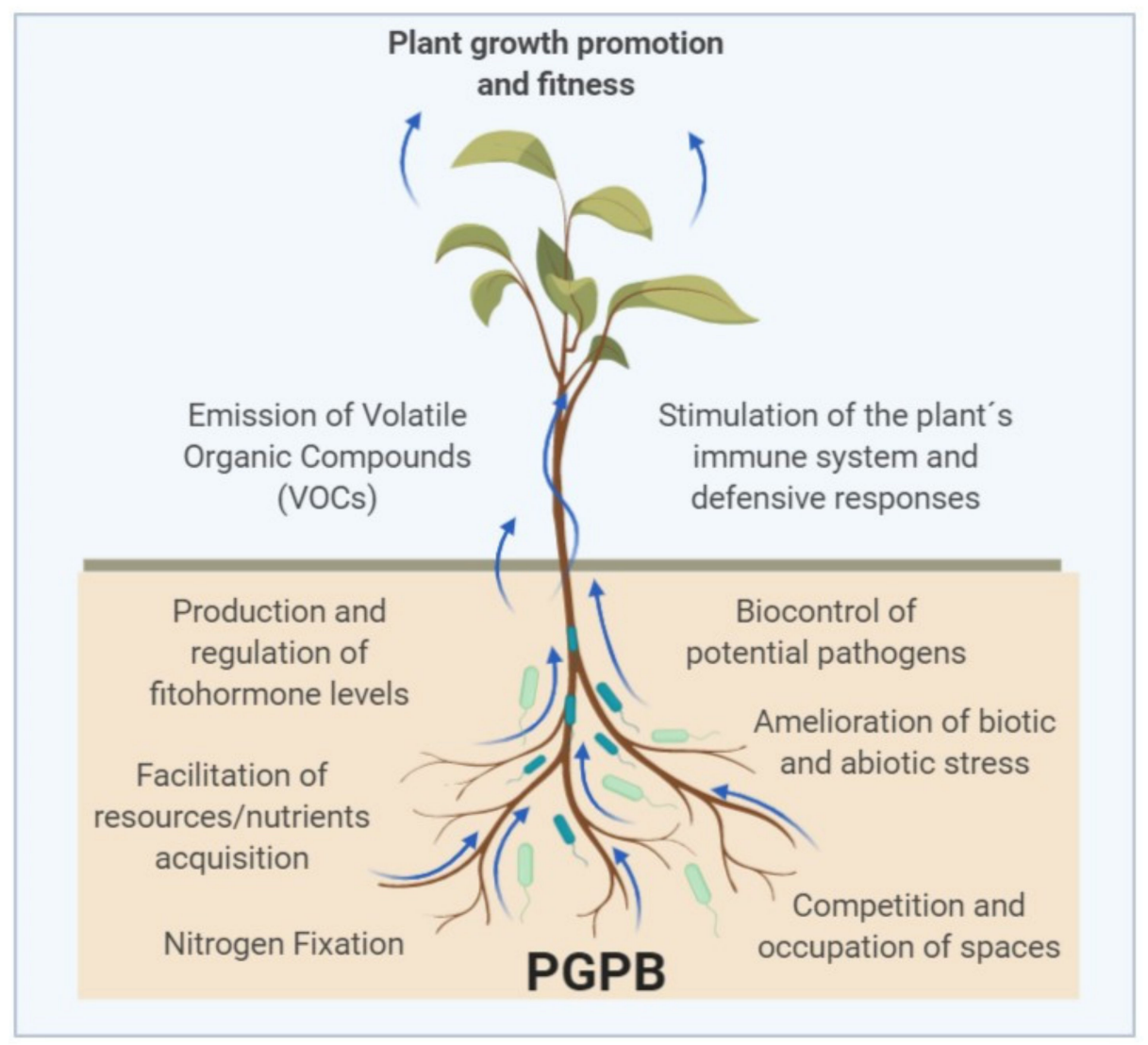

Figure 1. Beneficial mechanisms exerted by plant growth-promoting bacteria (PGPB) to stimulate healthy plant growth and fitness.

An element that is abundant in nature is iron, whose acquisition requires the formation of Fe-siderophore complexes. Siderophores are iron-chelating compounds secreted by bacteria that reduce iron $\left(\mathrm{Fe}^{3+}\right.$ to $\left.\mathrm{Fe}^{2+}\right)$ intra and intercellularly and can be used either by the plant or the endophyte. Siderophores have a relevant function when Fe is scarce in the environment [6]. One of the main endophytic bacterial genera is Pseudomonas. Characteristically, Pseudomonas species fluorescence is due to their different kinds of siderophores, such as pyochelin, pseudobactin, and pyoverdine. Several studies have shown that microbial siderophores can directly increase plant growth through the improvement in iron acquisition, since this element has several important biological functions for the cell [25]. For example, P. fluorescens strain C7 produces siderophores of the pyoverdine type, which forms a pyoverdine-Fe complex. This complex may be taken up by the plant Arabidopsis thaliana and increase its growth [26]. Microbial siderophores are synthesized by various taxa and may participate through indirect mechanisms in plant growth $[27,28]$, as reviewed below.

Nitrogen $(\mathrm{N})$ is another essential element for the development and production of fruits and seeds in plants of agricultural interest [29]. Leguminous plants may symbiotically interact with soil bacteria collectively known as rhizobia, which include the genera Bradyrhizobium, Sinorhizobium/Ensifer, Mesorhizobium, Rhizobium, Azorhizobium, Neorhizobium, and Pararhizobium. These are free-living bacteria (diazotrophic) that may penetrate 
plant tissues through the exchange of chemical signals and form nodules. Nodules are globular or cylindrical structures where rhizobial endophytes reside and are capable of fixing atmospheric nitrogen and converting it into ammonia, an assimilable form of nitrogen for the plant [30]. Some non-nitrogen-fixing bacteria, such as Pseudomonas, may stimulate the legume-rhizobia symbiosis in addition to increasing levels of nitrogen fixation, thus improving plant growth and nutrition. For example, the high activity levels of the enzyme 1-aminocyclopropane-1-carboxylate (ACC) deaminase detected in Pseudomonas are essential to enhance the nodulation process in rhizobia, showing that a beneficial interaction between bacteria may also benefit the plant [31]. Similar activities have been observed in other plant-bacteria models [32].

The production of phytohormones and other diffusible or volatile compounds that modulate plant growth is a relevant factor for potential endophytes that are candidates for being used as biostimulant products in agricultural crops [6]. The main hormones that stimulate plant growth are auxins, such as volatile organic compounds (VOC). Each of them has special functions to stimulate plant growth, in addition to being synthesized by the plant and fulfilling various physiological processes. For example, IAA participates in processes such as seed germination, formation of lateral roots, gravidity, and photosynthesis; it affects photosynthesis and the production of metabolites and other relevant compounds involved in the development of the plant $[6,10]$. Gibberellins and cytokinins also modulate a wide variety of processes, such as germination of seeds and cell elongation, primarily in the stem. The production of other compounds that stimulate plant growth and development, such as those of the diffusible or volatile type, has stood out in the last decade for their relevant role in plant-bacteria interactions, such as acetoin, 2,3-butanediol, and $N, N$-dimethylhexadecylamine [33-35]. Table 1 shows a summary of works describing some of the main direct mechanisms of plant growth promotion in bacteria.

\subsection{Indirect Mechanisms}

Indirect mechanisms include antagonism of PGPB towards potential phytopathogens. Restricting the growth or eliminating pathogens is an indirect mechanism for PGPB to promote the growth and health of the plant. PGPB contain an entire arsenal of compounds and enzymes that have the ability to restrict or eliminate pathogens. For example, the siderophores produced by bacteria of the genus Pseudomonas have the ability to chelate the Fe available from the medium, restricting it to pathogens. This mechanism was one of the first described in plant growth-promoting bacteria and has been reported in various studies [36].

Another mechanism widely used by bacterial endophytes with antifungal activity is the production of enzymes, such as chitinases, cellulases, and $\beta-1,3-$ glucanases that degrade the fungal cell wall. Chitinase degrades chitin, an insoluble linear polymer of $\beta-1,4-\mathrm{N}$-acetyl-glucosamine, known to be the major component of the fungal cell walls. Various bacteria that are part of the plant protective endobiome include species of Bacillus, such as B. licheniformis, B. cereus, B. subtilis, and B. thuringiensis. Martínez-Absalón et al. [37] demonstrated the relevant role of chitinase production in B. thuringiensis UM96. These researchers showed that, when using a chitinase inhibitor compound in UM96 strain supernatants, the biocontrol function towards the plant pathogen Botrytis cinerea decreased. $B$. cinerea is known to cause gray mold in more than 200 plant species. Other Gram-negative species, such as Pseudomonas, also produce various enzymes that directly attack the fungal cell wall [38].

Bacilli is one of the most studied groups of isolated endophytic and rhizospheric bacteria; the members of this group have been characterized as potential biocontrol agents [34]. The antagonistic abilities of Bacilli include the synthesis of various enzymes with antibiotic activity including peptides of ribosomal origin (polyketide synthases), such as subtilin, subtilosin A, TasA, and sublancin. Besides, Bacilli produce peptides of non-ribosomal origin, which are synthesized by non-ribosomal peptide synthetases, such as bacillaene, bacilysin, chlorotetain, difficidin, mycobacillin, and some rhizocticins [39]. The production 
of other volatile compounds such as ethylene, methyl salicylate, and methyl jasmonate may induce and control plant defense responses [33]. Plant defense responses stimulated by bacterial endophytes are widely reported in the literature, and their main function is to increase a series of actions that allow the plant to defend from the attack of pathogens [40]. Some recent works that exemplify the benefits of plant growth promoting bacteria and their application in different plant crops are listed in Table 1.

Table 1. Examples of works highlighting direct and indirect mechanisms of biocontrol and plant-growth promotion in plant-associated bacteria.

\begin{tabular}{|c|c|c|c|c|}
\hline $\begin{array}{l}\text { Bacterial Species } \\
\text { and Strain }\end{array}$ & $\begin{array}{l}\text { Mechanism and/or Benefit in } \\
\text { the Host Plant }\end{array}$ & Plant Host Species & $\begin{array}{l}\text { Type of Test or } \\
\text { Applied Technique }\end{array}$ & Reference \\
\hline $\begin{array}{l}\text { Bacillus subtilis ES748, } \\
\text { ES749 and a bacterial } \\
\text { consortium }\end{array}$ & $\begin{array}{l}\text { Synergistic interaction } \\
\text { between species }\end{array}$ & Arabidopsis thaliana & $\begin{array}{l}\text { Generation of mutants, } \\
\text { colonization and } \\
\text { maintenance assays } \\
\text { in vitro }\end{array}$ & {$[41]$} \\
\hline $\begin{array}{l}\text { Agrobacterium rhizogenes } \\
\text { K599 }\end{array}$ & $\begin{array}{l}\text { Improvement in the } \\
\text { acquisition of nitrogen and } \\
\text { change in the secretion of } \\
\text { organic compounds }\end{array}$ & Phaseolus vulgaris L. & $\begin{array}{l}\text { In vitro colonization assays } \\
\text { and microbial community } \\
\text { analysis }\end{array}$ & {$[42]$} \\
\hline $\begin{array}{l}\text { Pseudomonas umsongensis, } \\
\text { Arthrobacter defluvii, } \\
\text { Streptomyces gardneri, } \\
\text { Microbacterium yannicii, } \\
\text { Variovorax ginsengisoli, } \\
\text { Cupriavidus laharis, Bosea } \\
\text { vestrisii, Bosea robiniae }\end{array}$ & $\begin{array}{l}\text { Production of phytohormones, } \\
\text { secretion of siderophores and } \\
\text { stimulating effects }\end{array}$ & $\begin{array}{l}\text { Zea mays L., Populus } \\
\text { nigra and Arabidopsis } \\
\text { thaliana }\end{array}$ & $\begin{array}{l}\text { Detection of siderophores, } \\
\text { phytohormones and } \\
\text { colonization and } \\
\text { permanence tests in vitro } \\
\text { and in the field }\end{array}$ & {$[1,43]$} \\
\hline $\begin{array}{l}\text { Sinorhizobium meliloti } \\
2011\end{array}$ & $\begin{array}{l}\text { Improved nitrogen acquisition, } \\
\text { secretion of signaling } \\
\text { compounds }\end{array}$ & Medicago truncatula & $\begin{array}{l}\text { Detection of } \\
\text { nitrogen-fixing nodules } \\
\text { and in vitro colonization } \\
\text { assays }\end{array}$ & {$[44]$} \\
\hline Bacillus cereus YL6 & $\begin{array}{l}\text { Improved phosphorus } \\
\text { acquisition and phytohormone } \\
\text { biosynthesis }\end{array}$ & $\begin{array}{l}\text { Glycine max, Triticum } \\
\text { vulgare, Brassica rapa } \\
\text { subsp. pekinensis }\end{array}$ & $\begin{array}{l}\text { Phosphorus solubilization } \\
\text { test, in vitro and field } \\
\text { colonization test of plant } \\
\text { species }\end{array}$ & [45] \\
\hline $\begin{array}{l}\text { Pseudomonas aeruginosa } \\
\text { NXHG29 }\end{array}$ & $\begin{array}{l}\text { Dual antagonism, quorum } \\
\text { sensing, and biofilm formation }\end{array}$ & Nicotiana tabacum & $\begin{array}{l}\text { In vitro colonization and } \\
\text { antagonism assays }\end{array}$ & [46] \\
\hline $\begin{array}{l}\text { Pseudomonas stutzeri E25, } \\
\text { Stenotrophomas maltophilia } \\
\text { CR71 }\end{array}$ & $\begin{array}{l}\text { Antagonism, secretion of } \\
\text { volatile organic compounds } \\
\text { and synergism between } \\
\text { bacterial species }\end{array}$ & $\begin{array}{l}\text { Physalis ixocarpa, } \\
\text { Lycopersicon esculentum } \\
\text { cv Saladette }\end{array}$ & $\begin{array}{l}\text { In vitro antagonism, } \\
\text { promotion, colonization } \\
\text { and volatile compound } \\
\text { detection assays by GC-MS }\end{array}$ & [47] \\
\hline Bacillus cereus SA1 & $\begin{array}{l}\text { Production of phytohormones, } \\
\text { secretion of organic acids. } \\
\text { Improved the biomass and } \\
\text { chlorophyll content. }\end{array}$ & Glycine max & $\begin{array}{l}\text { Detection of } \\
\text { phytohormones, } \\
\text { HPLC compound } \\
\text { determination and assays } \\
\text { in plants. }\end{array}$ & [48] \\
\hline $\begin{array}{l}\text { Pseudomonas fluorescens } \\
\text { UM270 }\end{array}$ & $\begin{array}{l}\text { Genes involved in signaling, } \\
\text { antioxidant activities, secretion } \\
\text { systems, and biofilm } \\
\text { production }\end{array}$ & not applicable & $\begin{array}{l}\text { Genomic comparison } \\
\text { Pseudomonas strains }\end{array}$ & [49] \\
\hline $\begin{array}{l}\text { Bacillus megaterium, } \\
\text { Enterobacter C7 }\end{array}$ & $\begin{array}{l}\text { Improvement in the } \\
\text { acquisition of } \mathrm{Na}, \mathrm{Ca}, \mathrm{Mg} \text {, } \\
\text { production of antioxidants, } \\
\text { phytohormones and secretion } \\
\text { of secondary metabolites }\end{array}$ & Solanum lycopersicum & $\begin{array}{l}\text { Detection of } \\
\text { phytohormones, evaluation } \\
\text { in the change of metabolic } \\
\text { profiles by GC-MS and } \\
\text { in vitro colonization assay }\end{array}$ & {$[50]$} \\
\hline Bacillus subtilis SWR01 & $\begin{array}{l}\text { Genes involved in swarm } \\
\text { signaling and motility }\end{array}$ & Solanum lycopersicum & $\begin{array}{l}\text { Generation of mutants and } \\
\text { in vitro colonization assay }\end{array}$ & {$[51]$} \\
\hline $\begin{array}{l}\text { Bacillus thuringiensis } \\
\text { UM96, Pseudomonas } \\
\text { fluorescens UM16, UM240, } \\
\text { UM256, UM270 }\end{array}$ & $\begin{array}{l}\text { Synergistic interaction } \\
\text { between species and plant } \\
\text { growth stimulation of plants }\end{array}$ & Physalis ixocarpa & In vitro colonization assay & {$[2,52]$} \\
\hline
\end{tabular}


Table 1. Cont.

\begin{tabular}{|c|c|c|c|c|}
\hline $\begin{array}{l}\text { Bacterial Species } \\
\text { and Strain }\end{array}$ & $\begin{array}{l}\text { Mechanism and/or Benefit in } \\
\text { the Host Plant }\end{array}$ & Plant Host Species & $\begin{array}{l}\text { Type of Test or } \\
\text { Applied Technique }\end{array}$ & Reference \\
\hline Bacillus altitudinis KP-14 & $\begin{array}{l}\text { Production of phytohormones, } \\
\text { secretion of siderophores, } \\
\text { Improvement in the } \\
\text { acquisition of phosphorus, } \\
\text { Antagonism, secretion of } \\
\text { volatile organic compounds }\end{array}$ & $\begin{array}{l}\text { Miscanthus } \times \text { giganteus } \\
(M x g), \text { Brassica alba }\end{array}$ & $\begin{array}{l}\text { Detection of } \\
\text { phytohormones and } \\
\text { siderophores, phosphorus } \\
\text { solubilization test, in vitro } \\
\text { antagonism assays, volatile } \\
\text { compound detection } \\
\text { assays and assays in plants }\end{array}$ & [53] \\
\hline $\begin{array}{l}\text { Bacillus amyloliquefaciens } \\
\text { NJN-6 }\end{array}$ & $\begin{array}{l}\text { Organic compound secretion } \\
\text { and biofilm generation }\end{array}$ & Musa paradisiaca & $\begin{array}{l}\text { Chemotaxis Assays, } \\
\text { In Vitro Colonization } \\
\text { Assay, and HPLC } \\
\text { Compound Determination }\end{array}$ & {$[54]$} \\
\hline $\begin{array}{l}\text { Rhizobium etli G12, } \\
\text { Pseudomonas trivialis, } \\
\text { Pseudomonas jessenii, } \\
\text { Serratia plymuthica, } \\
\text { Bacillus subtilis Sb4-23, } \\
\text { Mc5-Re2, Mc2-Re2 }\end{array}$ & $\begin{array}{l}\text { Antibiosis, biofilm formation, } \\
\text { chemotaxis, phytohormone } \\
\text { production, secretion of toxic } \\
\text { compounds to nematodes and } \\
\text { induced systemic resistance }\end{array}$ & $\begin{array}{l}\text { Solanum lycopersicum } \mathrm{cv} \\
\text { moneymaker }\end{array}$ & $\begin{array}{l}\text { In vitro colonization and } \\
\text { antagonism assays }\end{array}$ & [55] \\
\hline $\begin{array}{l}\text { Paenibacillus polymyxa } \\
\text { CF05 }\end{array}$ & $\begin{array}{l}\text { Production of phytohormones, } \\
\text { secretion of antioxidants and } \\
\text { phenolic compounds }\end{array}$ & $\begin{array}{l}\text { Solanum lycopersicum cv } \\
\text { Zheza } 203\end{array}$ & $\begin{array}{l}\text { Antioxidant detection } \\
\text { assays, in vitro and } \\
\text { greenhouse antagonism } \\
\text { and colonization assays }\end{array}$ & [56] \\
\hline Bacillus subtilis HJ5 & $\begin{array}{l}\text { Antibiosis and biofilm } \\
\text { production }\end{array}$ & Gossypium herbaceum & $\begin{array}{l}\text { In vitro colonization and } \\
\text { antibiosis assays }\end{array}$ & [57] \\
\hline $\begin{array}{l}\text { Pseudomonas sp. } \\
\text { DSMZ } 13134\end{array}$ & $\begin{array}{l}\text { Improvement in the } \\
\text { acquisition of phosphorus, } \\
\text { secretion of siderophores, } \\
\text { antimicrobial compounds and } \\
\text { induction of systemic } \\
\text { resistance }\end{array}$ & Hordeum vulgare & $\begin{array}{l}\text { Phosphorus solubilization } \\
\text { test, siderophore detection, } \\
\text { antagonism and } \\
\text { colonization test in vitro }\end{array}$ & [58] \\
\hline $\begin{array}{l}\text { Kliebsella pneumoniae } \\
\text { NG14 }\end{array}$ & $\begin{array}{l}\text { Improved nitrogen acquisition } \\
\text { and biofilm production }\end{array}$ & Oryza sativa L. & $\begin{array}{l}\text { Detection of genes } \\
\text { associated with nitrogen } \\
\text { metabolism and in vitro } \\
\text { colonization assay }\end{array}$ & [59] \\
\hline $\begin{array}{l}\text { Azospirillum brasilense } \\
\text { SP245, SK048, } \\
\text { SK051, SK } 454\end{array}$ & Genes involved in motility & Triticum vulgare & $\begin{array}{l}\text { Generation of mutants and } \\
\text { in vitro colonization assay }\end{array}$ & {$[60]$} \\
\hline
\end{tabular}

\section{Formulation of Bioinoculants and Recommendations on Their Application}

There are several techniques to generate bioformulations containing PGPBs. There is solid (e.g., powder) or liquid formulations, where in some cases the application is more efficient and it is usual to maintain a good number of colony-forming units (CFUs), either in the soil or in the phyllosophere. Likewise, if the intention is to attack soil fungi or oomycetes, it is appropriate to apply the bioinoculant with antifungal activity in the soil, near the root. On the other hand, if the potential infection by pathogens is in the aerial part of the plants, the ideal is to do foliar application in liquid or powder [61].

In certain situations, the formulation depends on the objective of the application either in the field or in the greenhouse, whether in large or small areas of land. Likewise, the inoculation time is also relevant, either prophylactically or when there is already a certain infection caused by pathogens. In the case of the latter situation, the protective effect has not been as effective as the direct application of biocidal agrochemicals, which usually kill or directly damage pathogens, whether they are bacteria, fungi, oomycetes or viruses. The ideal in any case is to use bioinoculants before observing disease symptoms in plant crops, since the evidence suggests that their action is better when the antagonist is previously present, managing to protect even the products during post-harvest [62]. 
Now, if what the producer want is to apply a bioinoculant with a stimulating action on plant growth and development (biofertilizer or biostimulant), the best option is to apply it on seeds or during the first stages of plant growth (seedlings), in order to exert a greater promoting effect [63]. Likewise, some bioinoculants can have dual action, that is, certain species of bacteria such as Pseudomonas or Bacillus can exert direct action by stimulating plant growth and at the same time, antagonizing pathogens and/or stimulating plant defenses [34].

Although it has been proposed that the production of bioinoculants can be cheap and that the final product can also be cheaper than agrochemicals, there are still certain restrictions on their production [64]. Arora and colleagues [65] have identified some production and marketing constraints with developing efficient application of bioformulations, including: (i) the high cost of production; (ii) shelf life; and (iii) inconsistent performance in open field. Producing bioinoculants/bioformulations require certain biotechnological equipment and hi-tech instrumentation to large-scale production, and non-efficient handling procedures are a major cause of underperformance in open field application. Additionally, shelf life of the products depends on several factors, such as the culture medium, the physiological traits of the microbial species, the use of protective materials, the type of drying and rate of dehydration technology used. Finally, it is proposed that the inconsistent field results are the major constrain associated with the bioformulation marketing [65]. Therefore, it is important to avoid cell death of the microbial agents and to maintain good colony forming units of the inoculant. Additionally, to obtain better results in field, it is necessary to check out all the microbial agent specificities and see under what environmental circumstances the inoculum works better. Figure 2 summarizes the process of isolating bacteria as biocontrol agents and plant growth promoters, the necessary screening to identify the best strains and the appropriate tests to achieve the formulation of the bioinoculant.

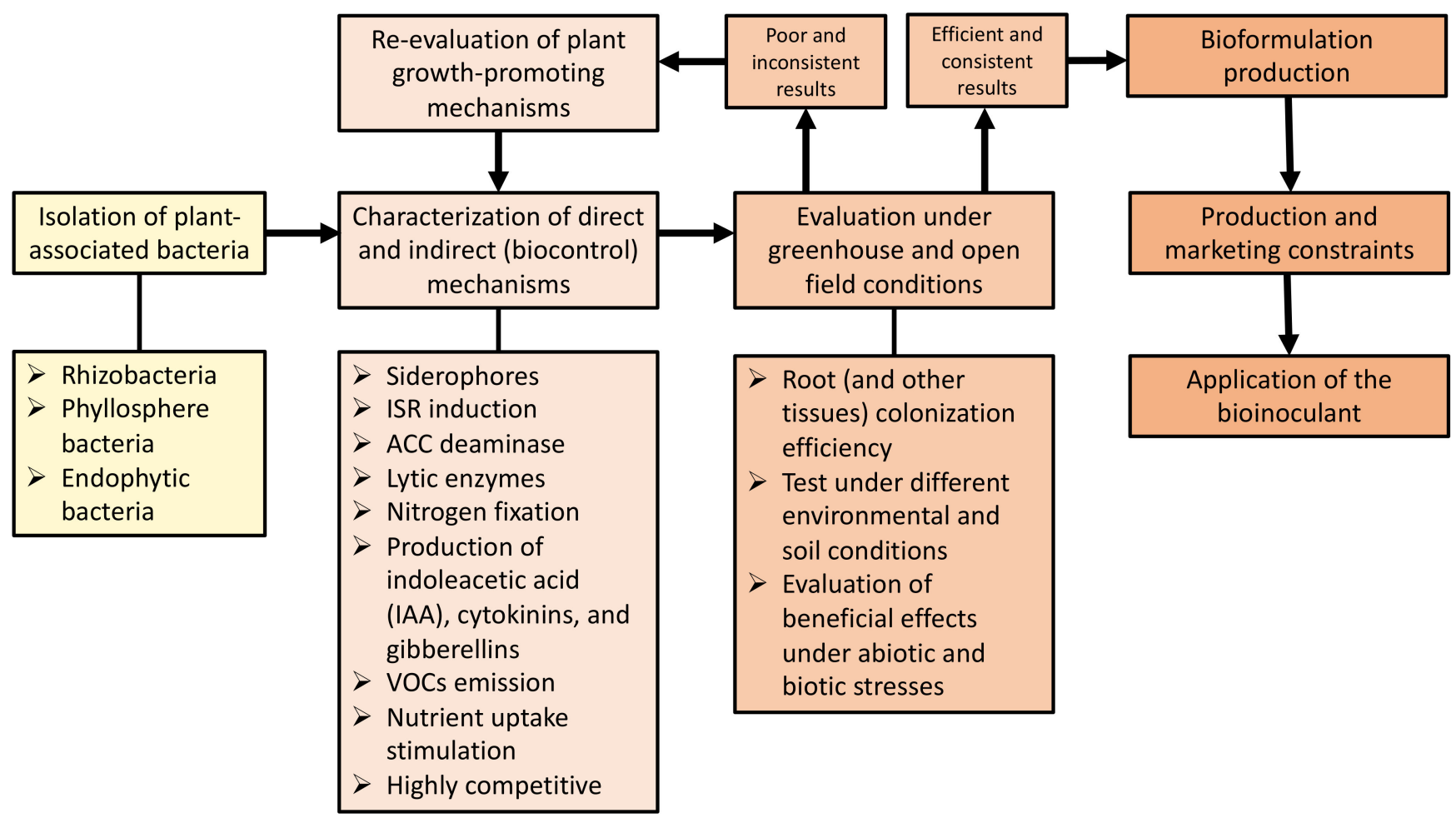

Figure 2. A summary of the processes to isolate and characterize bacteria as biocontrol agents and plant growth promoters, the preliminary screening to identify the best strains and the appropriate tests to achieve the formulation of the bioinoculant. Before successful application in open field conditions, bioinoculants should have passed through certain constraints (see text for details). 


\section{Challenges in the Application of Bioinoculants}

At a global level, the application of PGPB in the open field still requires breaking certain barriers that allow a broader use to stimulate the production and improvements of agricultural crops, as well as counteract the negative effects of potential phytopathogens [11]. There are still certain inconsistent results with some bioinoculants, whether they are biostimulants of plant growth or biopesticides, when applied in the field. The factors can be diverse, but a challenge is the lifetime that PGPB have as part of a bioinoculant. Some strains, such as Bacillus spp., can be applied in the form of spores, which prolongs their shelf life [27]. However, other non-sporulating strains require novel formulations that allow them to survive and maintain efficient viability until inoculation.

Once they have been inoculated in the field, it is desirable that the inoculated bacterial agents persist in the soil and colonize spaces such as the rhizosphere. Therefore, it is required to select and apply those strains that are highly competitive in the rhizosphere of plants, that are efficient colonizers of spaces and can exert their beneficial activities in such microenvironment $[12,13]$. The application of inoculants in powder or liquid form to the plant phyllosphere also presents certain challenges. For example, the weather conditions can be changeable and lower the efficiency if there is no adequate bacterial colonization and attachment to the leaves [17]. Therefore, some of these aspects can be technical and therefore, the development of suitable protocols can increase the effectiveness of bioinoculants.

On the other hand, the challenges faced by bioinoculants may be different around the world, for the simple fact that edaphic, climatic and geographical conditions are enormously variable [3,9]. For this reason, for decades it has been tried to isolate native strains that allow to improve the crops of the same localities from which they were isolated, which would suggest a better efficiency to exercise their beneficial actions when associated with plants in the same types of agricultural soils. For this reason, more research is required to associate abiotic aspects with the beneficial properties of each bioinoculant.

\section{Other Challenges of PGPB Application: The Case of Latin America}

With respect to the development and commercialization of bioinoculants around the world have occurred unevenly worldwide. While some European countries have taken important measures to limit the use of agrochemicals and stimulate the generation of bioinoculants, other countries, such as Mexico and some in Latin America (and other regions of the world) have not had the same response [66-68]. This situation persists despite international markets such as the United States of America, Canada, and other Asian and European countries having implemented restrictive measures on the importation of products produced using agrochemicals. Thus, questions arise as to why the development of bioinoculants has not been promoted in countries such as Mexico and others with similar conditions in Latin America.

Farmers in Mexico and several countries in Latin America own few hectares of orchards or farmland; they are called small-scale producers if they have up to five hectares. Some other definitions by the Food and Agriculture Organization of the United Nations suggest that landowners are small-scale producers if they have up to two hectares $[69,70]$. These small-scale producers require economic support to operate their farmland, for example, the provision of credit that would allow them to access seeds suitable for cultivation in the region where they live, as well as biofertilizers that would allow them to sustainably increase their production. Likewise, it is important that government policies promote the reduction of agrochemicals, so that small owners do not see their market limited locally or regionally, which would allow them to market their product at national and international levels. The Secretary of Agriculture and Rural Development of Mexico (https: / / www.gob.mx/agricultura, accessed on 1 March 2021) has various programs to support farmers in need of assistance; however, the bureaucracy and delay in the delivery of agricultural supplements can cause inefficient production systems. 
In the case of large-scale fruit producers, such as avocado producers, knowledge of the use of biofertilizers that improve the nutrition and production of crops should be promoted. If necessary, the prophylactic application of antifungal or biocidal microbial agents should be more widely used in orchards [71]. For example, 77\% of Mexico's avocado crop is produced in the State of Michoacán, with this country being the world's largest producer of this fruit. In the marketing year of 2016-2017, Mexico exported almost 895,000 tonnes of avocados to 26 countries, bringing in revenues of USD 2.5 billion [72]. This is an important income source for the families of Michoacán and Mexico. Therefore, the development of government policies that promote the use of bioinoculants (either biofertilizers or biocides) during fruit production is essential, especially given the high demand for organic products. In addition, the reduction and, ideally, the elimination of toxic chemicals would cause less damage to the garden workers themselves [73]. Such policies would also offer an alternative for small producers, who would see a higher income when marketing their products in other countries, without restrictions due to the use of agrochemicals.

Latin American countries share diverse historical, social, and cultural components. These countries originated from a mixture of millennial races that inhabited America long before the arrival of colonizers, who mainly came from Europe, Spain, Portugal, and France. These historical events have left these countries with a genetic footprint and a fairly similar cultural heritage [74]. In Mexico, there is no culture of prevention; only when a problem is visible, are steps taken to solve it. This is also the case for some farmers; they consider that it is not necessary to apply products in the field that could prevent potential infection by pathogens that could reduce crop yield. It is very difficult to "convince" farmers that bioinoculants can work preventatively in a similar way to a chemical fertilizer or fungicide. Therefore, it is necessary to work actively to change the mentality of small-scale producers. Both educational institutions and bioinoculant producing companies have an opportunity to provide education to farmers, making them aware of the ecological and economic benefits of using microbial inoculants.

The gross domestic product of Mexico and some Latin American countries is less than $1 \%$ that of countries such as Germany, Japan, or the United States, with these differences being significant [75]. This makes it more difficult to receive scientific research support in a country such as Mexico. In Mexico, research projects are mainly financed by the National Science and Technology Council and partly by internal funds from universities and higher education institutions; however, these are limited. This is not from a lack of will, but rather the fact that the universities themselves (the vast majority of which are public) depend on the federal government for financing. Furthermore, there are significant differences in the budgets for supporting research projects between universities in the capital and provinces. In some cases, there are universities and private institutions that generate high-quality science and make an effort to compete in generating knowledge. This affects not only the development of research on microbial bioinoculants, but all research from different fields of knowledge. An important factor that has not been widely explored is that of farmer inclusion in academic research projects [76,77].

Bureaucracy in Mexico and Latin America is an obstacle to development [78]. For Mexico, the creation of a new company is subject to endless requirements that can delay its inception. Likewise, the application and commercialization of products, including bioinoculants, are faced with various obstacles. There are some cases of ephemeral success in the production of bioinoculants, such as the case of a biofertilizer based on the application of the Azospirillum bacterium. The development of this biofertilizer (one of the first ones in our country) was undertaken by Dr. Jesús Caballero-Mellado, who recently passed away [79]; however, it was a project that was abandoned after a few years, due to lack of support. A more recent example is that of the first biofungicide based on the Bacillus sp. strain 83, Fungifree $A B^{\circledR}$, which was developed in Mexico by researchers from the National Autonomous University of Mexico and the Center for Food and Development Research, Culiacán Unit. The success of this product required the researchers themselves to create their own company to market their biofungicide [80]. This joint effort of institutions 
and researchers is highly commendable; however, not all institutions have the established statutes or internal policies to promote the development and generation of patents, or to promote the necessary agreements between the academy and the company. Additionally, scientists often lack experience beyond their laboratories and lack knowledge in areas such as high-scale production, marketing, and advertising [80]. This is where agreements with companies can promote strategies for the production and marketing of bioinoculants to achieve long-term success.

In general, in some countries, researchers isolate, characterize, and perform in vitro, greenhouse, and/or field research to test the capabilities of new microorganisms. Once their effectiveness has been proven, and the potential of specific activities to promote growth or biocontrol certain pathogens is known, the task of the researcher is complete. The entrepreneur can take over and produce and market the product, until it reaches the farmer. This process prevents researchers from spending time on tasks that are not their specialty, leaving the subject of marketing to the experts [81].

\section{Conclusions and Remarks}

Sustainable agriculture makes rational use of resources, in particular, soil, water, and agricultural inputs, for the production of vegetables, seeds, and fruit. Its objective is to achieve higher production in a small area to satisfy basic food needs, but it also involves the social and economic aspects of a society. One of the main focuses is on the reduction or elimination of agrochemical use through changes in management. These must ensure adequate nutrition, growth, production, and protection of plant crops [82]. To achieve this sustainable objective, various changes must be made to conventional strategies of food production, such as bridging basic and applied research [76]. It is important to change our way of thinking to be more eco-friendly and to open spaces for the discussion of proposals and public policies that promote the use of environmentally friendly strategies, such as the use of inoculants based on beneficial microorganisms, such as plant growth-promoting bacteria, including rhizosphere, phyllosphere and bacterial endophyte communities [7,83,84].

Finally, for thousands of years, civilizations such as that of the Mayans have valued the use of microorganisms (mainly mixtures of algae and cyanobacteria) to increase soil nutrients [85]. Today, we must continue the development of these technologies to improve crops via the application of microorganisms such as PGPB — knowledge that was already appreciated by the ancient civilizations of Mesoamerica, and that must continue to benefit future generations.

Author Contributions: Conceptualization, writing—original draft preparation, visualization, writingreview and editing, M.d.C.O.-M. and G.S.; writing-review and editing, A.F., B.R.-S., C.A.U.-F., L.R.M.-C., M.F.V.-M., S.C.-A., D.R.-S. All authors have read and agreed to the published version of the manuscript.

Funding: The work in our Laboratory is funded by Universidad Michoacana de San Nicolás de Hidalgo (2020) and Consejo Nacional de Ciencia y Tecnología de Mexico (Research Grant: A1-S-15956).

Institutional Review Board Statement: Not applicable.

Informed Consent Statement: Not applicable.

Data Availability Statement: Not applicable.

Conflicts of Interest: The authors declare no conflict of interest.

\section{References}

1. Pingali, P.L. Green Revolution: Impacts, limits, and the path ahead. Proc. Natl. Acad. Sci. USA 2012, 109, 12302-12308. [CrossRef]

2. Nicolopoulou-Stamati, P.; Maipas, S.; Kotampasi, C.; Stamatis, P.; Hens, L. Chemical Pesticides and Human Health: The Urgent Need for a New Concept in Agriculture. Front. Public Health 2016, 4, 148. [CrossRef]

3. Egamberdieva, D.; Lugtenberg, B. Use of Plant Growth-Promoting Rhizobacteria to Alleviate Salinity Stress in Plants. In Use of Microbes for the Alleviation of Soil Stresses; Springer: New York, NY, USA, 2014; Volume 1, pp. 73-96. 
4. Glick, B.R. Bacteria with ACC deaminase can promote plant growth and help to feed the world. Microbiol. Res. 2014, 169, 30-39. [CrossRef]

5. Orozco-Mosqueda, M.D.C.; Glick, B.R.; Santoyo, G. ACC deaminase in plant growth-promoting bacteria (PGPB): An efficient mechanism to counter salt stress in crops. Microbiol. Res. 2020, 235, 126439. [CrossRef] [PubMed]

6. Santoyo, G.; Sánchez-Yáñez, J.M.; Santos-Villalobos, S.D.L. Methods for Detecting Biocontrol and Plant Growth-Promoting Traits in Rhizobacteria. In Microbes and Signaling Biomolecules against Plant Stress; Springer: Singapore, 2019; pp. 133-149.

7. Santoyo, G.; Moreno-Hagelsieb, G.; Orozco-Mosqueda, M.D.C.; Glick, B.R. Plant growth-promoting bacterial endophytes. Microbiol. Res. 2016, 183, 92-99. [CrossRef] [PubMed]

8. Begum, N.; Qin, C.; Ahanger, M.A.; Raza, S.; Khan, M.I.; Ashraf, M.; Ahmed, N.; Zhang, L. Role of Arbuscular Mycorrhizal Fungi in Plant Growth Regulation: Implications in Abiotic Stress Tolerance. Front. Plant Sci. 2019, 10, 1068. [CrossRef] [PubMed]

9. Ojuederie, O.B.; Olanrewaju, O.S.; Babalola, O.O. Plant Growth Promoting Rhizobacterial Mitigation of Drought Stress in Crop Plants: Implications for Sustainable Agriculture. Agronomy 2019, 9, 712. [CrossRef]

10. Glick, B.R. Plant Growth-Promoting Bacteria: Mechanisms and Applications. Scientifica 2012, 2012, 963401. [CrossRef] [PubMed]

11. Glick, B.R. Issues Regarding the Use of PGPB. In Beneficial Plant-Bacterial Interactions; Springer: Cham, Switzerland, 2020.

12. Berendsen, R.L.; Pieterse, C.M.J.; Bakker, P.A.H.M. The rhizosphere microbiome and plant health. Trends Plant Sci. 2012, 17, 478-486. [CrossRef]

13. Hartmann, A.; Rothballer, M.; Schmid, M. Lorenz Hiltner, a pioneer in rhizosphere microbial ecology and soil bacteriology research. Plant Soil 2007, 312, 7-14. [CrossRef]

14. Mendes, R.; Kruijt, M.; de Bruijn, I.; Dekkers, E.; Van Der Voort, M.; Schneider, J.H.M.; Piceno, Y.M.; DeSantis, T.Z.; Andersen, G.L.; Bakker, P.A.H.M.; et al. Deciphering the Rhizosphere Microbiome for Disease-Suppressive Bacteria. Science 2011, 332, 1097-1100. [CrossRef]

15. Carvalho, S.D.; Castillo, J.A. Influence of Light on Plant-Phyllosphere Interaction. Front. Plant Sci. 2018, 9, 1482. [CrossRef] [PubMed]

16. Bunster, L.; Fokkema, N.J.; Schippers, B. Effect of Surface-Active Pseudomonas spp. on Leaf Wettability. Appl. Environ. Microbiol. 1989, 55, 1340-1345. [CrossRef] [PubMed]

17. Liu, H.; Brettell, L.E.; Singh, B. Linking the Phyllosphere Microbiome to Plant Health. Trends Plant Sci. 2020, 25, 841-844. [CrossRef]

18. Rodriguez, R.; Redman, R. More than 400 million years of evolution and some plants still can't make it on their own: Plant stress tolerance via fungal symbiosis. J. Exp. Bot. 2008, 59, 1109-1114. [CrossRef] [PubMed]

19. Hardoim, P.R.; Van Overbeek, L.S.; Berg, G.; Pirttilä, A.M.; Compant, S.; Campisano, A.; Sessitsch, A. The hidden world within plants: Ecological and evolutionary considerations for defining functioning of microbial endophytes. Microbiol. Mol. Biol. Rev. 2015, 79, 293-320. [CrossRef] [PubMed]

20. Schulz, B.; Boyle, C. The endophytic continuum. Mycol Res. 2005, 109, 661-687. [CrossRef]

21. Wani, Z.A.; Ashraf, N.; Mohiuddin, T.; Riyaz-Ul-Hassan, S. Plant-endophyte symbiosis, an ecological perspective. Appl. Microbiol. Biotechnol. 2015, 99, 2955-2965. [CrossRef]

22. Khatoon, Z.; Huang, S.; Rafique, M.; Fakhar, A.; Kamran, M.A.; Santoyo, G. Unlocking the potential of plant growth-promoting rhizobacteria on soil health and the sustainability of agricultural systems. J. Environ. Manag. 2020, 273, 111118. [CrossRef] [PubMed]

23. Mahdi, S.S.; Talat, M.A.; Dar, M.H.; Hamid, A.; Ahmad, L. Soil phosphorus fixation chemistry and role of phosphate solubilizing bacteria in enhancing its efficiency for sustainable cropping-A review. J. Pure. Appl. Microbiol. 2012, 6, $1905-1911$.

24. Mahanty, T.; Bhattacharjee, S.; Goswami, M.; Bhattacharyya, P.; Das, B.; Ghosh, A.; Tribedi, P. Biofertilizers: A potential approach for sustainable agriculture development. Environ. Sci. Pollut. Res. 2016, 24, 3315-3335. [CrossRef] [PubMed]

25. Saha, R.; Saha, N.; Donofrio, R.S.; Bestervelt, L.L. Microbial siderophores: A mini review. J. Basic Microbiol. 2013, 53, 303-317. [CrossRef] [PubMed]

26. Parray, J.A.; Jan, S.; Kamili, A.N.; Qadri, R.A.; Egamberdieva, D.; Ahmad, P. Current perspectives on plant growth promoting rhizobacteria. J. Plant Growth. Regul. 2016, 35, 877-902. [CrossRef]

27. Santoyo, G.; Orozco-Mosqueda, M.D.C.; Govindappa, M. Mechanisms of biocontrol and plant growth-promoting activity in soil bacterial species of Bacillus and Pseudomonas: A review. Biocontrol Sci. Technol. 2012, 22, 855-872. [CrossRef]

28. Vinale, F.; Nigro, M.; Sivasithamparam, K.; Flematti, G.; Ghisalberti, E.L.; Ruocco, M.; Varlese, R.; Marra, R.; Lanzuise, S.; Eid, A.; et al. Harzianic acid: A novel siderophore from Trichoderma harzianum. FEMS Microbiol. Lett. 2013, 347, 123-129. [CrossRef] [PubMed]

29. Mahmud, K.; Makaju, S.; Ibrahim, R.; Missaoui, A. Current Progress in Nitrogen Fixing Plants and Microbiome Research. Plants 2020, 9, 97. [CrossRef]

30. Batista, M.B.; Dixon, R. Manipulating nitrogen regulation in diazotrophic bacteria for agronomic benefit. Biochem. Soc. Trans. 2019, 47, 603-614. [CrossRef]

31. Nascimento, F.X.; Tavares, M.J.; Franck, J.; Ali, S.; Glick, B.R.; Rossi, M.J. ACC deaminase plays a major role in Pseudomonas fluorescens YsS6 ability to promote the nodulation of Alpha- and Betaproteobacteria rhizobial strains. Arch. Microbiol. 2019, 201, 817-822. [CrossRef] 
32. Zahir, Z.A.; Zafar-ul-Hye, M.; Sajjad, S.; Naveed, M. Comparative effectiveness of Pseudomonas and Serratia sp. containing ACC-deaminase for coinoculation with Rhizobium leguminosarum to improve growth, nodulation, and yield of lentil. Biol. Fertil Soils. 2011, 47, 457-465. [CrossRef]

33. Bitas, V.; Kim, H.-S.; Bennett, J.W.; Kang, S. Sniffing on Microbes: Diverse Roles of Microbial Volatile Organic Compounds in Plant Health. Am. Phytopathol. Soc. 2013, 26, 835-843. [CrossRef]

34. Hernández-León, R.; Rojas-Solís, D.; Contreras, M.; Orozco-Mosqueda, M.D.C.; Macías-Rodríguez, L.I.; de la Cruz, H.R.; ValenciaCantero, E.; Santoyo, G. Characterization of the antifungal and plant growth-promoting effects of diffusible and volatile organic compounds produced by Pseudomonas fluorescens strains. Biol. Control 2015, 81, 83-92. [CrossRef]

35. Montejano-Ramírez, V.; García-Pineda, E.; Valencia-Cantero, E. Bacterial Compound N,N-Dimethylhexadecylamine Modulates Expression of Iron Deficiency and Defense Response Genes in Medicago truncatula Independently of the Jasmonic Acid Pathway. Plants 2020, 9, 624. [CrossRef] [PubMed]

36. Kloepper, J.W.; Leong, J.; Teintze, M.; Schroth, M.N. Enhanced plant growth by siderophores produced by plant growth-promoting rhizobacteria. Nature 1980, 286, 885-886. [CrossRef]

37. Martínez-Absalón, S.; Rojas-Solís, D.; Hernández-León, R.; Prieto-Barajas, C.; Orozco-Mosqueda, M.D.C.; Peña-Cabriales, J.J.; Sakuda, S.; Valencia-Cantero, E.; Santoyo, G. Potential use and mode of action of the new strain Bacillus thuringiensis UM96 for the biological control of the grey mould phytopathogenBotrytis cinerea. Biocontrol Sci. Technol. 2014, 24, 1349-1362. [CrossRef]

38. Goswami, D.; Thakker, J.; Dhandhukia, P.C. Portraying mechanics of plant growth promoting rhizobacteria (PGPR): A review. Cogent Food Agric. 2016, 2, 1127500. [CrossRef]

39. Leclère, V.; Béchet, M.; Adam, A.; Guez, J.S.; Wathelet, B.; Ongena, M.; Jacques, P. Mycosubtilin overproduction by Bacillus subtilis BBG100 enhances the organism's antagonistic and biocontrol activities. Appl. Environ. Microbiol. 2005, 71, 4577-4584. [CrossRef]

40. Kloepper, J.W.; Ryu, C.M. Bacterial endophytes as elicitors of induced systemic resistance. In Microbial Root Endophytes; Soil Biology; Schulz, B.J.E., Boyle, C.J.C., Sieber, T.N., Eds.; Springer: Berlin/Heidelberg, Germany, 2006; Volume 9, pp. 33-52.

41. Eckshtain-Levi, N.; Harris, S.L.; Roscios, R.Q.; Shank, E.A. Bacterial Community Members Increase Bacillus subtilis Maintenance on the Roots of Arabidopsis thaliana. Phytobiomes J. 2020, 4, 303-313. [CrossRef]

42. Barraza, A.; Vizuet-De-Rueda, J.C.; Alvarez-Venegas, R. Highly diverse root endophyte bacterial community is driven by growth substrate and is plant genotype-independent in common bean (Phaseolus vulgaris L.). PeerJ 2020, 8, e9423. [CrossRef]

43. Bertola, M.; Mattarozzi, M.; Sanangelantoni, A.M.; Careri, M.; Visioli, G. PGPB Colonizing Three-Year Biochar-Amended Soil: Towards Biochar-Mediated Biofertilization. J. Soil Sci. Plant Nutr. 2019, 19, 841-850. [CrossRef]

44. Zhang, X.; Han, L.; Wang, Q.; Zhang, C.; Yu, Y.; Tian, J.; Kong, Z. The host actin cytoskeleton channels rhizobia release and facilitates symbiosome accommodation during nodulation in Medicago truncatula. New Phytol. 2018, 221, 1049-1059. [CrossRef]

45. Ku, Y.; Xu, G.; Tian, X.; Xie, H.; Yang, X.; Cao, C. Root colonization and growth promotion of soybean, wheat and Chinese cabbage by Bacillus cereus YL6. PLoS ONE 2018, 13, e0200181.

46. Ma, L.; Zhang, H.-Y.; Zhou, X.-K.; Yang, C.-G.; Zheng, S.-C.; Duo, J.-L.; Mo, M.-H. Biological control tobacco bacterial wilt and black shank and root colonization by bio-organic fertilizer containing bacterium Pseudomonas aeruginosa NXHG29. Appl. Soil Ecol. 2018, 129, 136-144. [CrossRef]

47. Rojas-Solís, D.; Zetter-Salmón, E.; Contreras-Pérez, M.; Rocha-Granados, M.D.C.; Macías-Rodríguez, L.; Santoyo, G. Pseudomonas stutzeri E25 and Stenotrophomonas maltophilia CR71 endophytes produce antifungal volatile organic compounds and exhibit additive plant growth-promoting effects. Biocatal. Agric. Biotechnol. 2018, 13, 46-52. [CrossRef]

48. Khan, M.A.; Asaf, S.; Khan, A.L.; Jan, R.; Kang, S.-M.; Kim, K.-M.; Lee, I.-J. Thermotolerance effect of plant growth-promoting Bacillus cereus SA1 on soybean during heat stress. BMC Microbiol. 2020, 20, 175. [CrossRef] [PubMed]

49. Hernández-Salmerón, J.E.; Hernández-León, R.; Orozco-Mosqueda, M.D.C.; Valencia-Cantero, E.; Moreno-Hagelsieb, G.; Santoyo, G. Draft Genome Sequence of the Biocontrol and Plant Growth-Promoting Rhizobacterium Pseudomonas fluorescens strain UM270. Stand. Genom. Sci. 2016, 11, 5. [CrossRef] [PubMed]

50. Ibort, P.; Molina, S.; Núñez, R.; Zamarreño, Á.M.; García-Mina, J.M.; Ruiz-Lozano, J.M.; Orozco-Mosqueda, M.D.C.; Glick, B.R.; Aroca, R. Tomato ethylene sensitivity determines interaction with plant growth-promoting bacteria. Ann. Bot. 2017, 120, 101-122. [CrossRef]

51. Gao, S.; Wu, H.; Yu, X.; Qian, L.; Gao, X. Swarming motility plays the major role in migration during tomato root colonization by Bacillus subtilis SWR01. Biol. Control 2016, 98, 11-17. [CrossRef]

52. Rojas-Solís, D.; Hernández-Pacheco, C.E.; Santoyo, G. Evaluation of Bacillus and Pseudomonas to colonize the rhizosphere and their effect on growth promotion in tomato (Physalis ixocarpa Brot. ex Horm.). Rev. Chapingo Ser. Hortic. 2016, 22, 45-57. [CrossRef]

53. Pranaw, K.; Pidlisnyuk, V.; Trögl, J.; Malinská, H. Bioprospecting of a Novel Plant Growth-Promoting Bacterium Bacillus altitudinis KP-14 for Enhancing Miscanthus $\times$ giganteus Growth in Metals Contaminated Soil. Biology 2020, 9, 305. [CrossRef]

54. Shen, Z.; Wang, B.; Lv, N.; Sun, Y.; Jiang, X.; Li, R.; Ruan, Y.; Shen, Q. Effect of the combination of bio-organic fertiliser with Bacillus amyloliquefaciens NJN-6 on the control of banana Fusarium wilt disease, crop production and banana rhizosphere culturable microflora. Biocontrol Sci. Technol. 2015, 25, 716-731. [CrossRef]

55. Adam, M.; Heuer, H.; Hallmann, J. Bacterial Antagonists of Fungal Pathogens also Control Root-Knot Nematodes by Induced Systemic Resistance of Tomato Plants. PLoS ONE 2014, 9, e90402. [CrossRef] 
56. Mei, L.; Liang, Y.; Zhang, L.; Wang, Y.; Guo, Y. Induced systemic resistance and growth promotion in tomato by an indole-3-acetic acid-producing strain ofPaenibacillus polymyxa. Ann. Appl. Biol. 2014, 165, 270-279. [CrossRef]

57. Li, X.; Rui, J.; Mao, Y.; Yannarell, A.; Mackie, R. Dynamics of the bacterial community structure in the rhizosphere of a maize cultivar. Soil Biol. Biochem. 2014, 68, 392-401. [CrossRef]

58. Fröhlich, A.; Buddrus-Schiemann, K.; Durner, J.; Hartmann, A.; von Rad, U. Response of barley to root colonization by Pseudomonas sp. DSMZ 13134 under laboratory, greenhouse, and field conditions. J. Plant. Interact. 2012, 7, 1-9. [CrossRef]

59. Liu, Y.; Wang, H.; Sun, X.; Yang, H.; Wang, Y.; Song, W. Study on Mechanisms of Colonization of Nitrogen-Fixing PGPB, Klebsiella pneumoniae NG14 on the Root Surface of Rice and the Formation of Biofilm. Curr. Microbiol. 2010, 62, 1113-1122. [CrossRef] [PubMed]

60. Shelud'Ko, A.V.; Shirokov, A.; Sokolova, M.K.; Sokolov, O.I.; Petrova, L.; Matora, L.Y.; Katsy, E.I. Wheat root colonization by Azospirillum brasilense strains with different motility. Microbiology 2010, 79, 688-695. [CrossRef]

61. Owen, D.; Williams, A.; Griffith, G.; Withers, P. Use of commercial bio-inoculants to increase agricultural production through improved phosphrous acquisition. Appl. Soil Ecol. 2015, 86, 41-54. [CrossRef]

62. Sreedhar, S.S.; Mohan, V. Effect of bio-inoculants on seed germination and disease control of commercially important fast growing native tree species in nursery. Kavaka 2014, 43, 41-45.

63. Kaymak, H.C. Potential of PGPR in Agricultural Innovations. In Plant Growth and Health Promoting Bacteria; Springer Science and Business Media LLC: Berlin/Heidelberg, Germany, 2010; pp. 45-79.

64. Wong, C.; Saidi, N.B.; Vadamalai, G.; Teh, C.Y.; Zulperi, D. Effect of bioformulations on the biocontrol efficacy, microbial viability and storage stability of a consortium of biocontrol agents against Fusarium wilt of banana. J. Appl. Microbiol. 2019, 127, 544-555. [CrossRef]

65. Arora, N.K.; Khare, E.; Maheshwari, D.K. Plant Growth Promoting Rhizobacteria: Constraints in Bioformulation, Commercialization, and Future Strategies. In Plant Growth and Health Promoting Bacteria; Microbiology Monographs; Springer Science and Business Media LLC: Berlin/Heidelberg, Germany, 2010; pp. 97-116.

66. Anriquez, A.L.; Silberman, J.E.; Nuñez, J.A.D.; Albanesi, A.S. Biofertilizers in Argentina. In Biofertilizers for Sustainable Agriculture and Environment; Soil Biology; Giri, B., Prasad, R., Wu, Q.S., Varma, A., Eds.; Springer: Cham, Switzerland, 2019; Volume 55, pp. 225-244.

67. Keswani, C.; Dilnashin, H.; Birla, H.; Singh, S.P. Regulatory barriers to Agricultural Research commercialization: A case study of biopesticides in India. Rhizosphere 2019, 11, 100155. [CrossRef]

68. Saritha, M.; Tollamadugu, N.P. The Status of Research and Application of Biofertilizers and Biopesticides: Global Scenario. In Recent Developments in Applied Microbiology and Biochemistry; Academic Press: Cambridge, MA, USA, 2019; pp. 195-207. [CrossRef]

69. Khalil, C.A.; Conforti, P.; Ergin, I.; Gennari, P. Defining Small Scale Food Producers to Monitor Target 2.3 of the 2030 Agenda for Sustainable Development. In FAO Statistics Division Working Paper Series ESS/17-12; Food and Agriculture Organization of the United Nations (FAO): Rome, Italy, 2017.

70. Durand, J.; Massey, D.S.; Zenteno, R.M. Mexican immigration to the United States: Continuities and changes. Lat. Am. Res. Rev. 2001, 36, 107-127. [PubMed]

71. Pierson, W.; Kandel, Y.; Allen, T.; Faske, T.; Tenuta, A.; Wise, K.; Mueller, D. Soybean Yield Response to In-furrow Fungicides, Fertilizers, and Their Combinations. Crop Forage Turfgrass Manag. 2018, 4, 1-9. [CrossRef]

72. Navarro, C. Mexico Continues to Promote Avocado Production, but Environmental Concerns Persist; University of New Mexico UNM Digital Repository: Albuquerque, NM, USA, 2018.

73. Wightwick, A.; Walters, R.; Allinson, G.; Reichman, S.; Menzies, S.R.A.N. Environmental Risks of Fungicides Used in Horticultural Production Systems. In Fungicides; InTech: Rijeka, Croatia, 2010; pp. 273-304. [CrossRef]

74. Stein, S.J.; Stein, B.H. La Herencia Colonial de América Latina/Colonial Heritage of Latin America; Siglo: Mexico City, Mexico, 2002; Volume 21.

75. Lancho-Barrantes, B.S.; Cantú-Ortiz, F.J. Science in Mexico: A bibliometric analysis. Scientometrics 2019, 118, 499-517. [CrossRef]

76. Chávez-Díaz, I.F.; Molina, L.X.Z.; Cárdenas, C.I.C.; Anaya, E.R.; Ramírez, S.R.; Villalobos, S.D.L.S. Consideraciones sobre el uso de biofertilizantes como alternativa agro- biotecnológica sostenible para la seguridad alimentaria en México. Rev. Mex. Cienc. Agrícolas 2020, 11, 1423-1436. [CrossRef]

77. López, K.; Carrillo, M.F.Z. Hacia la inclusión de los pequeños agricultores, población vulnerable, en programas de vigilancia toxicológica mediante la implementación de marcadores biológicos de fácil acceso en zonas rurales de Colombia. Rev. Int. Cienc. Soc. 2016, 5, 95-102.

78. Peeters, R.; Trujillo Jiménez, H.G.; O’Connor, E.; Ogarrio Rojas, P.; González Galindo, M.; Morales Tenorio, D.M. Low-Trust Bureaucracy: An Exploration of the Mechanisms and Costs of Administrative Burdens in Mexico. 2018. Available online: www.libreriacide.com/librospdf/DTAP-305.pdf (accessed on 1 April 2021).

79. López Reyes, L.; Tapia Hernández, A.; Jiménez Salgado, T.; Espinosa Victoria, D.; Carcaño Montiel, M.D. José de Jesús Caballero Mellado líder de la microbiología de suelos en México. Terra Latinoam. 2014, 32, 87-97.

80. Galindo, E.; Serrano-Carreón, L.; Gutiérrez, C.R.; Balderas-Ruíz, K.A.; Muñoz-Celaya, A.L.; Mezo-Villalobos, M.; Arroyo-Colín, J. Desarrollo histórico y los retos tecnológicos y legales para comercializar Fungifree $\mathrm{AB}^{\circledR}$, el primer biofungicida $100 \%$ mexicano. TIP. Rev. Espec. Cienc. Quím.Biol. 2015, 18, 52-60. [CrossRef] 
81. Tawate, S.; Gupta, R.; Jain, K. Technology Commercialization in Bio-fertilizer Firm: An Indian Case. Int. J. Bus. Compet. 2018, 13, 65-74.

82. Altieri, M.A. Agroecología: Principios y Estrategias para Diseñar Sistemas Agrarios Sustentables. In Agroecología: El Camino Hacia una Agricultura Sustentable; Sarandon, S.J., Ed.; Ediciones Científicas Americanas: Buenos Aires, Argentina, 2002 ; pp. 49-56.

83. Ortiz-Galeana, M.A.; Hernández-Salmerón, J.E.; Valenzuela-Aragón, B.; E Lossantos-Villalobos, S.D.; Rocha-Granados, M.D.C.; Santoyo, G. Diversidad de bacterias endófitas cultivables asociadas a plantas de arándano (Vaccinium corymbosum L.) cv. Biloxi con actividades promotoras del crecimiento vegetal. Chil. J. Agric. Anim. Sci. 2018, 34, 140-151. [CrossRef]

84. Flores, A.; Diaz-Zamora, J.T.; Orozco-Mosqueda, M.D.C.; Chávez, A.; Villalobos, S.D.L.S.; Valencia-Cantero, E.; Santoyo, G. Bridging genomics and field research: Draft genome sequence of Bacillus thuringiensis CR71, an endophytic bacterium that promotes plant growth and fruit yield in Cucumis sativus L. 3 Biotech 2020, 10, 1-7. [CrossRef]

85. Morrison, B.A.; Cozatl-Manzano, R. Initial Evidence for Use of Periphyton as an Agricultural Fertilizer by the Ancient Maya Associated with El Eden Wetland, Northern Quintana Roo, Mexico. In The Lowland Maya Area: Three Millennia at the HumanWildland Interface; Fedick, S., Allen, M., Jimenez-Osornio, J., Gomez-Pompa, A., Eds.; CRC Press: New York, NY, USA, 2003; pp. 401-413. 